\title{
PENGARUH PENYULUHAN KESEHATAN REPRODUKSI MELALUI AUDIO VISUAL DENGAN HASIL PENGETAHUAN SETELAH PENYULUHAN PADA REMAJA SMA NEGERI 2 PONTIANAK TAHUN 2017
}

\author{
Telly Khatarina ${ }^{1}$, Yuliana ${ }^{2}$
}

Akademi Kebidanan Panca Bhakti Pontianak

Email korespondensi: akbidpbpontianak@gmail.com

\begin{abstract}
Abstrak
Dewasa ini, usia remaja merupakan usia yang paling rawan mengalami masalah penyimpangan kesehatan reproduksi. Pengetahuan tentang kesehatan reproduksi sangat diperlukan oleh remaja agar meningkatkan pengetahuan tentang masalah kesehatan reproduksi. Salah satu cara untuk meningkatkan pengetahuan kesehatan reproduksi adalah dengan cara penyuluhan. Penyuluhan dengan audio visual adalah salah satu media yang menyajikan informasi atau pesan melalui lihat dan dengar sehingga semakin banyak panca indera yang digunakan maka semakin jelas pengetahuan yang diperoleh. Tujuan penelitian adalah untuk mengetahui pengaruh penyuluhan kesehatan reproduksi melalui audio visual dengan hasil pengetahuan setelah penyuluhan pada remaja SMA Negeri 2 Pontianak tahun 2017. Desain dalam penelitian ini menggunakan Eksperimen Seтu (Quasi Eksperimen) dengan rancangan One Group Pretest Post Test Design terhadap 32 siswa di bulan April dengan menggunakan kuesioner sebagai instrumen. Hasil penelitian sebelum penyuluhan sebagian besar dari responden $(65,6 \%)$ dengan jumlah 21 orang dikategorikan kurang dan sesudah penyuluhan hampir seluruh responden $(84,4 \%)$ dengan jumlah 27 orang dikategorikan baik. Diketahui hasil uji Paired Sample T-Test didapatkan bahwa nilai T hitung $<$ T tabel $(-10,74<$ -2,042) dan hasil uji statistik didapat nilai $p$ value $0,0001<$ alpha $(0,05)$ sehingga dapat disimpulkan bahwa Ho ditolak dan Ha diterima yaitu ada pengaruh penyuluhan kesehatan reproduksi melalui audio visual dengan hasil pengetahuan setelah penyuluhan. Kesimpulan dan saran dari penelitian ini adalah diajukan kepada siswa-siswi agar lebih meningkatkan pengetahuan tentang kesehatan reproduksi sehingga memiliki sikap dan perilaku kehidupan seksual yang sehat dan bertanggung jawab pada masa remaja.
\end{abstract}

Kata Kunci: Kesehatan Reproduksi, Audio Visual, Pengetahuan, Remaja

\section{Pendahuluan}

$$
\text { Kesehatan reproduksi merupakan }
$$

keadaan sehat secara fisik, mental dan sosial secara utuh, tidak semata-mata bebas dari penyakit atau kecacatan yang berkaitan dengan sistem, fungsi dan proses reproduksi. Ruang lingkup pelayanan kesehatan reproduksi menurut International Conference Population and Development (ICPD) tahun 1994 di Kairo terdiri dari kesehatan ibu dan anak, keluarga berencana, pencegahan dan penanganan infeksi menular seksual termasuk HIV/AIDS, kesehatan reproduksi remaja, pencegahan dan penanganan komplikasi aborsi, pencegahan dan penanganan infertilitas, kesehatan reproduksi usia lanjut, deteksi dini kanker saluran reproduksi serta

\footnotetext{
${ }^{1}$ Dosen Akademi Kebidanan Panca Bhakti Pontianak

${ }^{2}$ Dosen Akademi Kebidanan Panca Bhakti Pontianak
}

kesehatan reproduksi lainnya seperti kekerasan seksual, sunat perempuan dan sebagainya (KemenKes RI, 2014).

Kesehatan reproduksi sama halnya dengan kesehatan pada umumnya adalah hak setiap manusia. Pengetahuan tentang kesehatan reproduksi sangat diperlukan oleh masyarakat, khususnya penduduk remaja. Survei World Health Organization (WHO) tahun 2014, kelompok usia remaja (10-19 tahun), usia remaja merupakan usia yang paling rawan mengalami masalah kesehatan reproduksi seperti kehamilan usia dini, aborsi yang tidak aman, Infeksi Menular Seksual (IMS) termasuk Human Immunodeficiency Virus (HIV), 
pelecehan seksual dan perkosaan. Sebagai contoh, angka remaja wanita usia 15-19 tahun yang melahirkan pada tahun 2014 mencapai 49 per 1000 orang.

Menurut Torsina (2008), remaja juga merupakan masa kritis dalam perkembangan perilaku individu. Sewaktu berusia remaja seseorang seringkali mencoba perilaku yang modern dan baru trend. Perilaku-perilaku tersebut tidak selalu mengarah pada kebaikan, tetapi banyak diantaranya yang membawa risiko pada kesehatannya misalnya masalah seks bebas atau seks pranikah yang belakangan ini menjadi trend dikalangan remaja. Dengan perilaku buruk itu pula, para remaja sekarang rentan terhadap risiko gangguan kesehatan seperti penyakit HIV/AIDS, penggunaan narkoba, serta penyakit lainnya.

Menurut data World Health Organization (WHO) tahun 2014, menunjukkan bahwa angka kejadian kehamilan remaja di dunia dikalangan wanita yang berusia 15 sampai 19 tahun adalah 49 per 1.000 perempuan. Angka kejadian kehamilan remaja di Indonesia adalah 48 per 1.000 perempuan. Angka kejadian kehamilan remaja di Indonesia tergolong tinggi dibandingkan 6 di Malaysia dan 41 di Thailand (World Bank Group).

Riset Kesehatan Dasar (RISKESDAS) tahun 2013 memperlihatkan, terdapat kehamilan pada umur kurang dari 15 tahun sebanyak $0,02 \%$ dan kehamilan pada umur 1519 tahun sebesar 1,97\%. Sedangkan Survei Demografi dan Kesehatan Indonesia (SDKI) tahun 2012 menunjukkan bahwa 17\% perempuan sebelum usia 18 tahun sudah menikah dan pernikahan diantara anak perempuan berusia 15 tahun adalah $3 \%$. Pernikahan remaja terbanyak terjadi di pedesaan pada perempuan berstatus pendidikan rendah dan berasal dari keluarga berstatus ekonomi rendah.

Semakin muda seorang perempuan menikah maka akan berdampak pada segi psikologis seperti mengalami kecemasan, depresi, atau memiliki pikiran untuk bunuh diri disebabkan kurangnya kesiapan menjadi seorang istri, pasangan seks dan seorang ibu. Dan semakin muda usia seorang ibu ketika hamil, semakin besar risiko terhadap kesehatannya.

Menurut United Nations Children's Fund (UNICEF) tahun 2015 bahwa anak perempuan usia 10-14 tahun memiliki risiko lima kali lebih besar untuk meninggal dalam kasus kehamilan dan persalinan dari pada perempuan usia 20-24 tahun dan secara global kematian yang disebabkan oleh kehamilan merupakan penyebab utama kematian anak perempuan usia 15-19 tahun. Komplikasi yang jauh lebih tinggi berhubungan dengan persalinan pada anak perempuan, seperti fistula obstetri, infeksi, perdarahan hebat, anemia dan eklampsia. Sehingga untuk mencegah permasalahan tersebut diperlukan pendidikan kesehatan maupun pengetahuan tentang kesehatan reproduksi di kalangan remaja.

Pengetahuan merupakan hasil dari tahu, dan ini terjadi setelah seseorang melakukan penginderaan terhadap suatu objek tertentu. Penginderaan terjadi melalui penglihatan, penciuman, rasa, raba, dan sebagian besar pengetahuan manusia diperoleh melalui mata dan telinga (Notoatmodjo, 2010). Perlunya 
remaja mengetahui kesehatan reproduksinya adalah untuk meningkatkan pengetahuan remaja tentang kesehatan reproduksi sehingga memiliki sikap dan perilaku kehidupan seksual yang sehat dan bertanggung jawab pada masa remaja (Widyastuti, 2009).

Remaja (Adolsen) merupakan masa transisi dari anak-anak menjadi dewasa. Pada periode ini berbagai perubahan terjadi baik perubahan hormonal, fisik, psikologis maupun sosial. Perubahan ini terjadi dengan sangat cepat dan terkadang tanpa kita sadari. Perubahan fisik yang menonjol adalah perkembangan tanda-tanda seks sekunder, terjadinya pacu tumbuh, serta perubahan perilaku dan hubungan sosial dengan

lingkungannya. Perubahan- perubahan tersebut dapat mengakibatkan kelainan maupun penyakit tertentu bila tidak diperhatikan dengan seksama. Maturasi seksual terjadi melalui tahapan-tahapan yang teratur yang akhirnya mengantarkan anak siap dengan fungsi fertilitasnya, laki-laki dewasa dengan spermatogenesis, sedangkan anak perempuan dengan ovulasi. Di samping itu, juga terjadi perubahan psikososial anak baik dalam tingkah laku, hubungan dengan lingkungan serta ketertarikan dengan lawan jenis. Perubahanperubahan tersebut juga dapat menyebabkan hubungan antara orang tua dengan remaja menjadi sulit apabila orang tua tidak memahami proses yang terjadi (Pediatri, 2010).

Penyuluhan kesehatan reproduksi remaja merupakan pendidikan kesehatan yang dilakukan dengan menyebarkan pesan, menanamkan keyakinan sehingga remaja tidak saja sadar, tahu dan mengerti tetapi juga mau dan dapat melakukan anjuran yang berhubungan dengan kesehatan reproduksi (Maulana, 2009). Keberhasilan penyuluhan kesehatan pada remaja tergantung kepada komponen pembelajaran. Media penyuluhan kesehatan merupakan alat yang digunakan oleh pendidik dalam menyampaikan bahan pendidikan atau pengajaran.

Menurut penelitian para ahli, panca indera yang paling banyak menyalurkan pengetahuan ke otak adalah mata (kurang lebih $75 \%$ sampai $87 \%$ ), sedangkan $13-25 \%$ pengetahuan manusia diperoleh atau disalurkan melalui indera lainnya sehingga semakin banyak panca indera yang digunakan maka semakin jelas pengetahuan yang diperoleh. Audio visual merupakan salah satu media yang menyajikan informasi atau pesan melalui dengar dan lihat (Machfoedz, 2009).

Menurut Benita (2012), bahwa penyuluhan memiliki pengaruh yang signifikan terhadap tingkat pengetahuan kesehatan reproduksi remaja siswa SMP Kristen Gergaji. Hasil penelitian didapatkan bahwa terdapat peningkatan pengetahuan pada topik anatomi fisiologi organ reproduksi, cara memelihara kesehatan organ reproduksi, serta Penyakit Menular Seksual (PMS) dan HIV/AIDS.

Hasil penelitian yang dilakukan oleh Setiawati di SMP Negeri 9 Surakarta pada tahun 2014 yang berjudul "Pengaruh penyuluhan kesehatan reproduksi melalui metode ceramah terhadap tingkat pengetahuan kesehatan reproduksi pada siswa SMP Negeri 9 Surakarta" diperoleh perbedaan tingkat pengetahuan yang bermakna setelah diberikan penyuluhan $(\mathrm{p}<0,05)$. Pada hasil penelitian 
didapatkan nilai rata-rata terendah yaitu 1,35 pada hasil pretest, kemudian setelah penyuluhan atau diberikan perlakuan dilanjutkan post test dengan hasil rata-rata yaitu 2,55 dan sesudah 20 hari penyuluhan didapatkan nilai rata-rata yaitu sebesar 2,104.

Demikian juga, penelitian yang dilakukan oleh Massolo, dkk, di SMAN 1 Masohi pada tahun 2011 yang berjudul "Pengaruh penyuluhan kesehatan reproduksi terhadap pengetahuan dan sikap remaja tentang seksual pranikah di SMAN 1 Masohi tahun 2011" diperoleh hasil bahwa pemberian penyuluhan kesehatan reproduksi memberikan peningkatan terhadap pengetahuan dan sikap remaja tentang seksual pranikah. Uraiannya yaitu terjadi peningkatan pengetahuan siswa tentang seksual pranikah sebelum $(27,60)$ dan sesudah $(35,00)$ pada responden eksperimen dan pada responden control terjadi penurunan pada tingkat pengetahuan yakni 33,40 pada pretest menurun menjadi 26,00 pada saat post test. Juga terjadi peningkatan sikap pada responden eksperimen tentang seksual pranikah sebelum $(28,96)$ dan sesudah $(37,10)$ penyuluhan, dan pada control terjadi penurunan sikap yakni 32,02 saat pretest menjadi 23,90 saat post test.

Siswa-siswi di SMA Negeri 2 Pontianak adalah seorang remaja. Remaja merupakan usia yang paling rawan mengalami masalah penyimpangan kesehatan reproduksi, diusia remaja sebaiknya tindakan pencegahan dengan peningkatan pengetahuan tentang kesehatan reproduksi perlu ditingkatkan, sehingga tidak akan berdampak pada tindakan kekerasan, seperti pemerkosaan, pencabulan, pemaksaan kehendak atau melakukan penyerangan seksual dan lain sebagainya.

\section{Metode}

Penelitian ini menggunakan jenis penelitian eksperimen semu dengan rancangan one group pretest post test design. Penelitian dilaksanakan pada bulan Januari hingga Mei 2017 di SMA Negeri 2 Pontianak. Populasi penelitian yaitu siswa-siswi SMA Negeri 2 Pontianak sebanyak 319 orang. Peneliti menggunakan $10 \%$ total sampling sebanyak 32 orang. Pengumpulan data menggunakan kuesioner kemudian diolah dan dianalisis menggunakan analisis univariat serta analisis bivariat menggunakan uji paired sample T-Test.

\section{Hasil dan Pembahasan}

Tabel 1. Karakteristik Responden

\begin{tabular}{|c|c|c|c|c|}
\hline \multirow{2}{*}{ Karakterisik } & \multicolumn{2}{|c|}{$\begin{array}{c}\text { Sebelum diberikan } \\
\text { Penyuluhan }\end{array}$} & \multicolumn{2}{|c|}{$\begin{array}{c}\text { Sesudah diberikan } \\
\text { Penyuluhan }\end{array}$} \\
\hline & $\mathrm{n}$ & $\%$ & $\mathrm{n}$ & $\%$ \\
\hline \multicolumn{5}{|l|}{ Pengetahuan } \\
\hline Kurang & 21 & 65,6 & 5 & 15,6 \\
\hline Baik & 11 & 34,4 & 27 & 84,4 \\
\hline
\end{tabular}

Berdasarkan tabel 1 menunjukan bahwa Berdasarkan tabel 1 menunjukan bahwa hampir sebagian besar dari responden $(65,6 \%)$ dengan seluruh responden $(84,4 \%)$ dengan jumlah 27 jumlah 21 orang dikategorikan kurang. orang dikategorikan baik. 
Tabel 2. Analisis Bivariat

Penyuluhan

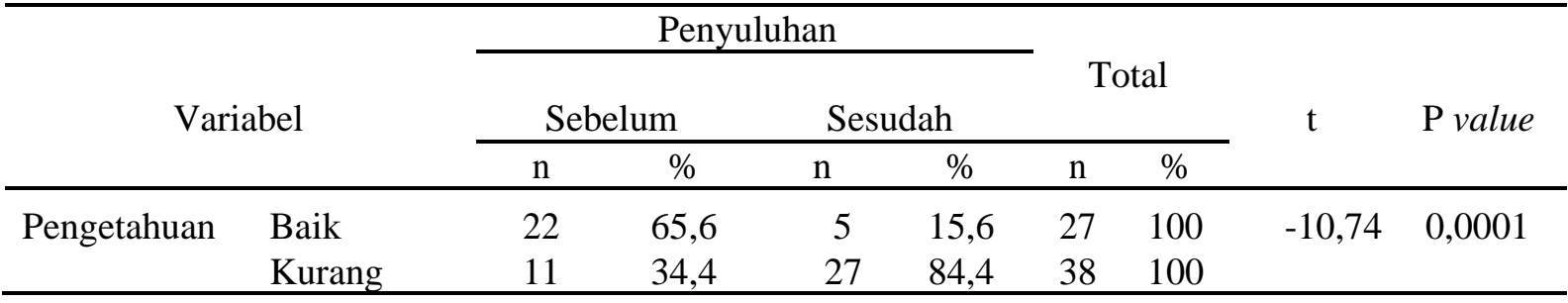

Berdasarkan tabel 2 di atas menunjukan bahwa pengetahuan sebelum dan sesudah diberikan penyuluhan melalui audio visual, pada data sebelum didapatkan bahwa sebagian besar dari responden $(65,6 \%)$ dengan jumlah 21 orang dikategorikan kurang dan sesudah

Tabel 3. Hasil Uji Paired Sample T-Test Pengetahuan Sebelum dan Sesudah Penyuluhan

\begin{tabular}{lcccccr}
\hline \multicolumn{1}{c}{ Variabel } & Mean & $\mathrm{N}$ & $\begin{array}{c}\text { Standar } \\
\text { Deviasi }\end{array}$ & $\begin{array}{c}\text { Standar } \\
\text { Error Mean }\end{array}$ & T Hitung & P value \\
\hline $\begin{array}{l}\text { Pengetahuan } \\
\text { Pre Test }\end{array}$ & 86 & 32 & 0,483 & 0,085 & & \\
Post Test & 99 & 32 & 0,369 & 0,065 & $-10,74$ & 0,0001 \\
\hline
\end{tabular}

Berdasarkan tabel 3 di atas didapakan hasil penelitian bahwa terdapat perbedaan nilai pretest dan post test pengetahuan. Nilai rata-rata pretest pengetahuan adalah 86 , standar deviation 0,483 dengan standar error mean sebesar 0,085 sedangkan nilai rata-rata post test penyuluhan bahwa hampir seluruh responden $(84,4 \%)$ dengan jumlah 27 orang dikategorikan baik. Hasil uji statistik didapatkan bahwa nilai Thitung $<$ T tabel $(-10,74<-2,042)$ dan $p$ Value 0,0001 .

pengetahuan adalah 99, standar deviation 0,369 dengan standar error mean sebesar 0,065 menunjukan bahwa nilai post test pengetahuan lebih tinggi dibandingkan dengan nilai pretest pengetahuan dengan perbedaan selisih nilai 13 angka.

Tabel 4. Hasil Uji Independent Sample T-Test Pengetahuan Sebelum dan Sesudah Penyuluhan

\begin{tabular}{cccccr}
\hline & Kategori & Mean & $\begin{array}{c}\text { Standar Error } \\
\text { Mean }\end{array}$ & N & P Value \\
\hline Pengetahuan & & & & & \\
$\quad$ Pretest & 66,39 & 14,946 & 1,761 & 72 & 0,0001 \\
Posttest & 75,56 & 10,992 & 1,295 & & \\
& & & & & \\
Praktik & 58,50 & 12,964 & 1,528 & \\
Pretest & 88,22 & 15,632 & 1,842 & \\
Posttest & & &
\end{tabular}

Berdasarkan tabel 4 di atas didapatkan hasil penelitian bahwa rata-rata nilai pretest dan post test adalah 0,5 , standar deviation 0,568 dengan standar error mean 0,1 dan derajat kebebasan (df) adalah 31. Hasil uji statistik didapat nilai $P$ Value 0,0001 , bearti pada alpha 
5\% dapat disimpulkan bahwa Ho ditolak dan $\mathrm{Ha}$ diterima adalah ada pengaruh penyuluhan kesehatan reproduksi melalui audio visual dengan hasil pengetahuan setelah penyuluhan.

Dari hasil penelitian sebelum penyuluhan didapatkan bahwa rata-rata pretest pengetahuan adalah 86, standar deviation 0,483, standar error mean sebesar 0,085 dan sebagian kecil dari responden $(34,4 \%)$ dengan jumlah 11 orang dikategorikan baik dan sebagian besar dari responden $(65,6 \%)$ dengan jumlah 21 orang dikategorikan kurang. Pengetahuan merupakan hasil dari tahu dan ini terjadi setelah seseorang melakukan penginderaan terhadap suatu objek tertentu. Penginderaan terjadi melalui penglihatan, penciuman, rasa, raba, dan sebagian besar pengetahuan manusia diperoleh melalui mata dan telinga (Notoatmodjo, 2010).

Hasil penelitian yang dilakukan oleh Massolo, dkk, di SMAN 1 Masohi pada tahun 2011 yang berjudul "Pengaruh penyuluhan kesehatan reproduksi terhadap pengetahuan dan sikap remaja tentang seksual pranikah di SMAN 1 Masohi tahun 2011" diperoleh hasil bahwa pemberian penyuluhan kesehatan reproduksi memberikan peningkatan terhadap pengetahuan dan sikap remaja tentang seksual pranikah. Uraiannya yaitu terjadi peningkatan pengetahuan siswa tentang seksual pranikah sebelum $(27,60)$ dan sesudah $(35,00)$ pada responden eksperimen dan pada responden control terjadi penurunan pada tingkat pengetahuan yakni 33,40 pada pretest menurun menjadi 26,00 pada saat post test. Juga terjadi peningkatan sikap pada responden eksperimen tentang seksual pranikah sebelum $(28,96)$ dan sesudah $(37,10)$ penyuluhan, dan pada control terjadi penurunan sikap yakni 32,02 saat pretest menjadi 23,90 saat post test.

Hal ini juga sependapat dengan penelitian yang dilakukan oleh Setiawati di SMP Negeri 9 Surakarta pada tahun 2014 yang berjudul "Pengaruh penyuluhan kesehatan reproduksi melalui metode ceramah terhadap tingkat pengetahuan kesehatan reproduksi pada siswa SMP Negeri 9 Surakarta" diperoleh perbedaan tingkat pengetahuan yang bermakna setelah diberikan penyuluhan $(\mathrm{p}<0,05)$. Pada hasil penelitian didapatkan nilai rata-rata terendah yaitu 1,35 pada hasil pretest, kemudian setelah penyuluhan atau diberikan perlakuan dilanjutkan post test dengan hasil rata-rata yaitu 2,55 dan sesudah 20 hari penyuluhan didapatkan nilai rata-rata yaitu sebesar 2,104.

Peneliti berpendapat bahwa pengetahuan didapat melalui hasil mecari tahu setelah melakukan pengindraan terhadap suatu objek tertentu. Hal inilah yang menyebabkan terdapat pengetahuan kurang $(65,6 \%)$ pada siswa sebelum dilakukan penyuluhan karena sebelum diberikan penyuluhan mereka belum mendapatkan informasi yang baru yang akan mereka ketahui.

Dari hasil penelitian yang dilakukan peneliti setelah dilakukan penyuluhan didapatkan bahwa rata-rata post test pengetahuan adalah 99, standar deviation 0,369 , standar error mean sebesar 0,065 dan hampir seluruh responden $(84,4 \%)$ dengan jumlah 27 orang dikategorikan baik dan sangat sedikit dari responden $(15,6 \%)$ dengan jumlah 5 orang dikategorikan kurang. 
Penyuluhan kesehatan reproduksi remaja merupakan pendidikan kesehatan yang dilakukan dengan menyebarkan pesan, menanamkan keyakinan sehingga remaja tidak saja sadar, tahu dan mengerti tetapi juga mau dan dapat melakukan anjuran yang berhubungan dengan kesehatan reproduksi (Maulana, 2009). Keberhasilan penyuluhan kesehatan pada remaja tergantung kepada komponen pembelajaran. Media penyuluhan kesehatan merupakan alat yang digunakan oleh pendidik dalam menyampaikan bahan pendidikan atau pengajaran (Machfoedz, 2009).

Hasil penelitian yang dilakukan oleh Benita di SMP Kristen Gergaji pada tahun 2012 yang berjudul "Pengaruh Penyuluhan terhadap Tingkat Pengetahuan Kesehatan Reproduksi pada Remaja Siswa SMP Kristen Gergaji” bahwa penyuluhan memiliki pengaruh yang signifikan terhadap tingkat pengetahuan kesehatan reproduksi remaja siswa SMP Kristen Gergaji. Hasil penelitian didapatkan bahwa terdapat peningkatan pengetahuan pada topik anatomi fisiologi organ reproduksi, cara memelihara kesehatan organ reproduksi, serta Penyakit Menular Seksual (PMS) dan HIV/AIDS

Hal ini juga sependapat dengan penelitian yang dilakukan oleh Udu pada tahun 2014 yang berjudul "Pengaruh intervensi penyuluhan terhadap pengetahuan dan sikap remaja tentang kesehatan reproduksi" bahwa terdapat pengaruh intervensi penyuluhan terhadap pengetahuan dan sikap perilaku remaja tentang kesehatan reproduksi. Penyuluhan tentang kesehatan reproduksi remaja meningkatkan pengetahuan dan sikap baik siswa maupun siswi serta kelompok IPA maupun IPS serta tidak terdapat perbedaan yang signifikan pada peningkatan rata-rata skor pengetahuan dan sikap antara siswa dan siswi serta antara kelompok IPA dan IPS.

Peneliti berpendapat bahwa penyuluhan kesehatan reproduksi melalui audio visual memiliki pengaruh yang signifikan terhadap pengetahuan kesehatan reproduksi. Penyuluhan inilah yang menyebabkan pengetahuan remaja dikategorikan baik $(84,4 \%)$ karena sesudah diberikan penyuluhan mereka sudah mendapatkan informasi yang baru sehingga diharapkan setelah remaja mengetahui dan mengerti tentang kesehatan reproduksi, remaja juga mau melakukan anjuran yang berhubungan dengan kesehatan reproduksinya.

Setelah dilakukan penelitian didapatkan hasil bahwa pengetahuan siswa sebelum dilakukan penyuluhan sebagian kecil dari responden mendapatkan kategori baik yaitu 11 orang $(34,4 \%)$ sedangkan setelah dilakukan penyuluhan hampir seluruh responden mendapatkan kategori baik yaitu 27 orang $(84,4 \%)$. Dan didapatkan hasil penelitian bahwa rata-rata nilai pretest dan post test adalah 0,5 , standar deviation 0,568 dengan standar error mean 0,1 dan derajat kebebasan (df) adalah 31 . Penelitian ini membuktikan bahwa T hitung $\mathrm{T}$ tabel $(-10,74<-2,042)$ dan juga didapatkan nilai $P$ Value $=0,0001<$ alpha $(0,05)$ sehingga disimpulkan bahwa Ho ditolak dan Ha diterima sehingga secara statistika terdapat pengaruh antara penyuluhan kesehatan reproduksi melalui audio visual dengan hasil pengetahuan.

Menurut Machfoedz (2009), bahwa panca indera yang paling banyak menyalurkan 
pengetahuan ke otak adalah mata (kurang lebih $75 \%$ sampai $87 \%$ ), sedangkan 13-25\% pengetahuan manusia diperoleh atau disalurkan melalui indera lainnya sehingga semakin banyak panca indera yang digunakan maka semakin jelas pengetahuan yang diperoleh. Audio visual merupakan salah satu media yang menyajikan informasi atau pesan melalui dengar dan lihat. Media sebagai alat peraga digunakan dalam rangka atau bertujuan untuk kemudahan dalam menyampaikan pesan. Alat peraga disusun berdasarkan prinsip bahwa pengetahuan yang ada pada manusia diterima atau ditangkap melalui panca indera (Hikmawati, 2011).

Hasil penelitian yang dilakukan oleh Nurmilah (2014), yang berjudul "Efektivitas pendidikan kesehatan reproduksi remaja di SMA Muhammadiah IV dan SMA Trampil Jakarta Timur, bahwa penyuluhan memiliki pengaruh yang signifikan terhadap tingkat pengetahuan remaja siswa/I SMA Muhammadiah IV. Dalam hal ini, penyuluhan yang dilakukan berupa ceramah dengan alat bantu audio visual diberikan hand-out serta diberikan kasus sesuai materi yang diselesaikan secara kelompok yang dipresentasikan.

Hal ini juga sependapat dengan penelitian yang dilakukan oleh Winarni (2016), bahwa penyuluhan dengan audio visual dalam bentuk ceramah lebih efektif dikarenakan pemberi ceramah lebih mengontrol dan lebih cepat mengetahui sampai dimana kemampuan siswa memahami materi yang diajarkan. Pada metode audio visual siswa dituntut untuk belajar secara mandiri sehingga tidak lagi berpusat pada penyuluh melainkan berpusat pada siswa sehingga siswa membutuhkan kemampuan abstraksi yang tinggi. Dalam penyampaian bimbingan atau penyuluhan penerapan audio visual tidak dapat berdiri sendiri sehingga masih memerlukan metode atau pendekatan seperti diskusi, ceramah dan lain sebagainya.

\section{Kesimpulan}

Berdasarkan hasil penelitian yang telah dilakukan, maka dapat disimpulkan bahwa terdapat pengaruh antara penyuluhan kesehatan reproduksi melalui audio visual dengan hasil pengetahuan. Hal ini disebabkan karena sebelum diberikan penyuluhan mereka belum mendapatkan informasi yang baru yang akan mereka ketahui sedangkan pada saat sesudah diberikan penyuluhan mereka sudah mendapatkan informasi-informasi yang baru. Sehingga penyuluhan kesehatan reproduksi sangat dibutuhkan khususnya pada remaja dan diharapkan memiliki sikap dan perilaku kehidupan seksual yang sehat dan bertanggung jawab.

\section{Daftar Pustaka}

Arikunto, S. 2006. Prosedur penelitian suatu pendekatan praktisi. Jakarta: Rineka Cipta

Astuti, Tika Fajar Ari Widi. 2015. Pengaruh Penyuluhan Kesehatan Reproduksi melalui Media Audio Visual terhadap Tingkat Pengetahuan dan Sikap tentang Kehamilan Remaja di Luar Nikah di SMK 17 Bantul Yogyakarta. Skripsi. Sekolah Tinggi Ilmu Kesehatan Aisyiyah Yogyakarta. Diakses: tanggal 3 Mei 2017, pukul 16.00 WIB

Benita, Nydia Rena. 2012. Pengaruh Penyuluhan terhadap Tingkat Pengetahuan Kesehatan Reproduksi pada Remaja Siswa SMP Kristen Gergaji. Karya Tulis Ilmiah. 
Universitas Diponegoro. Diakses: tanggal 2 April 2017, pukul 20.00 WIB

BKKBN. 2012. Buku Suplemen Bimbingan Teknis Kesehatan Reproduksi: Infeksi Menular Seksual dan HIV/AIDS. Jakarta: BKKBN

Dharma, Kelana Kusuma. (2012). Metodologi Penelitian Keperawatan Panduan Melaksanakan dan Menerapkan Hasil Penelitian. Jakarta: Trans Info Media

Hasibuan, Romauli, dkk. 2015. Faktor-faktor yang Mempengaruhi Kejadian Seks Pranikah pada Remaja Putri di SMAN 1 Pagai Utara Selatan Kabupaten Kepulauan Mentawai. Binawidya Pekanbaru. Diakses: tanggal 2 April 2017, pukul 20.00 WIB

Hikmawati, Isna. 2011. Promosi Kesehatan untuk Kebidanan. Yogyakarta: Numed

Isgiyanto, Awal. 2009. Teknik Pengambilan Sampel pada Penelitian Non Eksperimen. Yogyakarta: Mitra Cendikia Press

Kemenkes RI. 2014. Situasi Kesehatan Reproduksi Remaja. Jakarta: Depkes

Machfoedz, Ircham dan Eko Suryani. 2009. Pendidikan Kesehatan Bagian dari Promosi Kesehatan. Yogyakarta: Fitramaya

Maulana, Heri D.J. 2009. Promosi Kesehatan. Jakarta: EGC

Maryanti, Dwi dan Majestika Septikasari. 2009. Buku Ajar Kesehatan Reproduksi Teori dan Praktikum. Yogyakarta: Muha Medika

Massolo, Ardin Prima, dkk. 2011. Pengaruh Penyuluhan Kesehatan Reproduksi terhadap Pengetahuan dan Sikap Remaja tentang Seksual Pranikah di SMA 1 Masohi tahun 2011. Universitas Hasanuddin Makassar. Diakses: tanggal 20 Febuari 2017, pukul 17.00 WIB

Notoatmodjo, S. (2010). Metodologi Penelitian Kesehatan. Jakarta: Rineka Cipta
Nurmilah, dkk. 2014. Efektivitas Pendidikan Kesehatan Reproduksi Remaja di SMA Muhammadiah IV dan SMA Trampil Jakarta Timur. Poltekes Kemenkes Jakarta III. Diakses: tanggal 2 April 2017, pukul 16.00 WIB

Pediatri, Sari. 2010. Adolescent Development (Perkembangan Remaja). Fakultas Kedokteran Universitas Indonesia. Diakses: tanggal 20 Febuari 2017, pukul 17.00 WIB

Prawirohardjo, S. 2012. Ilmu Kebidanan. Jakarta: PT Bina Pustaka Sarwono Prawirohardjo

Rahyani, Ni Komang Yuni. 2012. Kesehatan Reproduksi Buku Ajar Bidan. Jakarta: EGC

Riskesdas. 2013. Riset Kesehatan Dasar. Jakarta: Depkes

Riyanto, Agus. 2013. Statistik Deskriptif (Untuk Kesehatan). Yogyakarta: Nuha Medika

Romauli, Suryati dan Anna Vida Vindari. 2012. Kesehatan Reproduksi Buat Mahasiswi Kebidanan. Yogyakarta: Muha Medika

Suherdi, Fauzan. 2015. Pengetahuan, Sikap dan Perawatan Diri Klien dengan Rematik yang Tinggal di Wilayah Puskesmas Muaro Bodi Kecamatan IV Nagari Kabupaten Sijunjung Sumatera Barat. Skripsi. Universitas Sumatera Utara. Diakses: Tanggal 12 Mei 2017, Pukul 15.00 WIB

Survei Demografi dan Kesehatan Indonesia (SDKI). 2012. Kesehatan Reproduksi Remaja. Jakarta: Depkes

Setiawati, Karina Aisyah. 2014. Pengaruh Penyuluhan Kesehatan Reproduksi melalui Metode Ceramah terhadap Tingkat Pengetahuan Kesehatan Reproduksi pada Siswa SMP Negeri 9 Surakarta. Skripsi. Universitas Muhamadiyah Surakarta. Diakses: tanggal 20 Febuari 2017, pukul 17.00 WIB 
Sulistyawati, Ari. 2012. Asuhan Kebidanan pada Masa Kehamilan. Jakarta: Salemba Medika

Swarjana, Ketut. 2014. Metodologi Penelitian Kesehatan Edisi Revisi. Yogyakarta: ANDI.

Syafrudin dan Yudhia Fratidhina. 2009. Promosi Kesehatan untuk Mahasiswa Kebidanan. Jakarta: Trans Info Media

Torsina, M. 2008. Tanya Jawab Seputar Seks Pasca Remaja (Edisi Revisi). Jakarta: PT Buana Ilmu Populer (BIP)

Udu, Waode Sitti Asfiah dan Putu Yayuk Widyani Wiradirani. 2014. Pengaruh Intervensi Penyuluhan terhadap Pengetahuan dan Sikap Remaja tentang Kesehatan Reproduksi. FK UHO. Diakses: tanggal 1 April 2017, pukul 14.00 WIB

UNICEF. 2015. Kemajuan yang Tertunda: Analisis Data Perkawinan Usia Anak di Indonesia. Jakarta: Badan Pusat Statistik

Widyastuti, Yani, dkk. 2009. Kesehatan Reproduksi. Yogyakarta: Fitramaya

WHO. 2016. Adolescents: health risks and solutions. World Health Organization

Winarni, Iffatun Rosyidah. 2016. Efektivitas Ceramah dan Audio Visual dalam Peningkatan Pengetahuan Dismenorea pada Siswi SMA. Diakses: tanggal 3 Mei 2017, pukul 16.00 WIB

Yanti. 2011. Buku Ajar Kesehatan Reproduksi untuk Mahasiswa Kebidanan. Yogyakarta: Pustaka Rihama. 